борьбы с паразитарными болезнями: матер. науч. конф. ВОГ РАН. М., 2013. Вып. 14. С. 182-185.

3. Андреянов О.Н., Успенский А.В., Горохов В.В., Хрусталев А.В., Бундина Л.А. Гельминтозоонозы промысловых плотоядных животных Центрального региона России // Теория и практика борьбы с паразитарными болезнями: матер. науч. конф. ВОГ РАН. М., 2016. Вып. 17. С. 25-26.

4. Малышева Н.С., Самофалова Н.А., Вагин Н.А. и др. Особенности циркуляции возбудителей зоонозов на территории Курской области и риск заражения ими человека // Уч. зап. Электр. науч. журнал Курского гос. ун-та. № 3 (23). Курск, 2012. 5 с.

5. Успенский А.В., Скворцова Ф.К. Метод ветеринарно-санитарной экспертизы мяса промысловых животных при паразитарных зоонозах // Российский паразитологический журнал. 2014. № 3. С. 151-156.

6. Борисенко Н.Е., Кроневальд О.В. Ветеринарносанитарная экспертиза продуктов убоя при выявленных инвазионных болезнях животных // Ветеринарно-санитарная экспертиза продуктов вынужденного убоя животных, при выявлении болезней и при изменениях, возникающих в процессе хранения мяса. Барнаул, 2006. С. 114-139.

7. Скворцова Ф.К., Успенский А.В. Диагностическая эффективность АВТ-Л6 для выявления бескап- сульных личинок трихинелл // Теория и практика борьбы с паразитарными болезнями: мат-лы докл. научн. конф. М., 2006. С. 375-378.

8. Андреянов О.Н. Современные пепсины в диагностике трихинеллеза // Новые методы экспрессдиагностики микроорганизмов в медицине, фармации, ветеринарии и экологии: мат-лы всерос. науч.практ. конф. 2015. С. 22-26.

9. Успенский А.В., Бессонов А.С., Шеховцев Н.В., Гребенкин С.А. Методические рекомендации по применению аппаратов для выделения личинок при ветеринарно-санитарной экспертизе туш и мясопродуктов // Тр. Всероссийского ин-та гельминтологии им. К.И. Скрябина. М., 2005. Т. 41. С. 447-452.

10. Гребенкина Л.А. Усовершенствование метода пептолиза с целью повышения эффективности трихинеллоскопического контроля // Российский паразитологический журнал. 2008. № 4. С. 57-59.

11. Гребенкина Л.А. Послеубойная диагностика трихинеллеза животных: автореф. дис. ... канд. биол. наук. М., 2010. 20 с.

12. Андреянов О.Н., Скворцова Ф.К. К дифференциальной диагностике возбудителя трихинеллеза // Ветеринария: научно-производственный журнал. 2013. № 8. C. 32-36.

\title{
LABORATORY DIAGNOSIS OF TRADE ANIMALS' TRICHINOSIS
}

\section{(C) 2017}

Andreyanov Oleg Nikolayevich, doctor of veterinary sciences, senior researcher of Parasitic Zoonosis Laboratory All-Russian Research Institute of Fundamental and Applied Parasitology of animals and plants named after K.I. Scriabin (Moscow, Russian Federation)

Abstract. In this paper the author considers the possibility of using an automated method of diagnostics of the causative agent of trichinosis Trichinella spp. at wild trade animals. In the course of trichinosis monitoring in the Central region of Russia naturally infested carcasses of animals were selected. The infected animals were stored at a low $\left(-5^{\circ} \mathrm{C}\right)$ temperature in the climatic camera before carrying out researches. With the help of AVT devices diagnostic tests on trichinosis of different types of trade animals' muscular tissue samples (diaphragm, masseter, extremities muscles, tongue) were conducted. During the research refrigerated and later cooled muscles samples were used. Samples weighing $50 \pm 0,5 \mathrm{~g}$. were used for the research. To get qualitative mincemeat fat and connective tissue were removed from muscular tissue. Pepsin produced by «Shako» (Rostov region) was used for an artificial peptoliz. Diagnostic samples of boars, foxes, martens increased the weighing mass to 40 minutes, of wolves to 50 minutes and of raccoon dogs to 60 minutes. Further tissue was fermented and weighing mass of the researched samples was decreased. The optimal period of time was found for trichinellascopy test of wild animals' muscular tissue by the automated method on AVT devices.

Keywords: AVT devices; period; digestion intensity; artificial gastric juice; diagnostics; diaphragm; muscular tissue; tests; pepsin; trade wild animals; hydrochloric acid; trichinellascopy; Central Region of Russia; Trichinella spp. activator.

УДК 578

\section{ДИНАМИКА ЗАРАЖЕННОСТИ КЛЕЩЕЙ ВИРУСОМ КЛЕЩЕВОГО ЭНЦЕФАЛИТА В НЕКОТОРЫХ РАЙОНАХ КИРОВСКОЙ ОБЛАСТИ}

(C) 2017

\author{
Бессолицына Екатерина Андреевна, кандидат биологических наук, доцент кафедры микробиологии \\ Ноздрина Елена Васильевна, студент института биологии и биотехнологии \\ Волков Станислав Александрович, аспирант кафедры микробиологии \\ Вятский государственный университет (2. Киров, Российская Федераџия)
}

\footnotetext{
Аннотация. В данном исследовании изучалась динамика зараженности вирусом клещевого энцефалита (европейской и сибирской изоформ) популяции клещей, собранных в период с 2007 по 2016 гг. с растительного покрова, домашних животных и одежды человека в городе Кирове, Кирово-Чепецком, Оричевском, Зуевском, Слободском и Тужинском районах Кировской области. Все собранные образцы проанализированы на наличие в них РНК-вируса клещевого энцефалита. Изоформы вируса выявлялись методом обратной тран-
} 
скрипции - полимеразной цепной реакции (ОТ-ПЦР). Анализ выявил динамику доли клещей, зараженных изоформами вируса клещевого энцефалита. В центральных районах области, имеющих общие границы, наблюдается совпадение пиков зараженности европейской изоформой вируса, однако для определения периодичности необходимы более продолжительные исследования. Также отмечено, что для некоторых районов характерно расширение пиков зараженности и увеличение времени между ними. Низкий процент зараженности на территории города Киров связан с обработкой территории акарицидами. С 2011 года в Кировской области наблюдаются случаи заражения клещей сибирской изоформой вируса клещевого энцефалита. Каждый год наблюдается интенсивное проникновение сибирской изоформы на запад по территории области. Периодичность появления этой изоформы составляет примерно 3 года.

Ключевые слова: клещевой энцефалит; вирус клещевого энцефалита; изоформы вируса клещевого энцефалита; Dermacentor reticulatus; Ixodes persulcatus; иксодовые клещи; РНК; идентификация; обратная транскрипция; полимеразная цепная реакция; Кировская область; город Киров.

\section{Актуальность исследований}

Клещевой энцефалит - вирусное природноочаговое трансмиссивное заболевание, характеризующееся поражениями оболочек серого и белого веществ головного и спинного мозга ЦНС, а также корешков спинномозговых нервов и периферических нервов, что приводит к развитию парезов и параличей. Заболевание может привести к стойким неврологическим, психиатрическим осложнениям и летальному исходу [1]. Возбудителем инфекции является вирус клещевого энцефалита.

Вирус клещевого энцефалита - РНК-содержащий вирус рода Flavivirus семейства Flaviviridae. Относится в экологической группе арбовирусов и переносится в основном клещами рода Ixodes [2]. На данный момент вирус представлен тремя изоформами: дальневосточной, сибирской и европейской [3].

Согласно исследованиям, в основном в Европе вирусом клещевого энцефалита инфицированы клещи вида Ixodes ricinus. Однако на территории Российской Федерации данный вирус выявляется также у клещей вида Ixodes persulcatus [4]. Кроме того, наблюдается рост количества клещей вида Dermacentor reticulatus, в организмах которых также обнаружен вирус клещевого энцефалита [5; 6].

Хотя изоформы вируса клещевого энцефалита географически преобладают в районах, соответствующих названиям изоформ, они постепенно появляются в других регионах. Например, сибирская изоформа встречается на территории Финляндии, Прибалтики и европейской части России, дальневосточная изоформа обнаружена также в европейской части России. Таким образом, с каждым годом границы ареалов клещей, а вместе с ним и ареалов инфекции, размываются и расширяются. Это касается многих регионов страны, в том числе Кировской области [7; 8].

Целью работы является изучение динамики процента зараженности клещей изоформами вируса клещевого энцефалита в различных районах Кировской области в период с 2007 по 2016 гг.

Материаль и методы исследования

Сбор клещей проводили с растительного покрова на движущегося учетчика и флаг или волокушу из вафельной ткани размером $60 \times 100 \mathrm{~cm}$ [9], а также вручную с одежды людей и домашних животных (собак, кошек).

Идентификацию клещей, выделенных из природных источников, проводили по определительным таблицам Н.А. Филипповой [10].

\section{Выделение РНК}

Суммарные нуклеиновые кислоты экстрагировали с помощью гуанидинтиоизоцианатного метода [11] из клещей, фиксированных в 70\% этиловом спирте.
Анализ на наличие генома вируса клещевого эниефалита

Исследование нуклеиновых кислот, выделенных из клещей, проводили с использованием обратной транскрипции-полимеразной цепной реакции (ОTПЦР). Для проведения реакции обратной транскрипции был использован праймер: TBEV-R 5'-ctc-atg-ttcagg-ccc-aac-ca-3' [12].

Для амплификации использовали следующие пары праймеров:

Для Европейской изоформы:

TBEV-E(F) 5'-aca-ccg-gag-act-atg-ttg-ccg-ca-3';

TBEV-E(R) 5' -ccg-ttg-gaa-ggt-gtt-ca-ct-3';

Для Сибирской изоформы:

TBEV-S(F) 5' -g(g/t)g-gat-gtg-tca-cga-tca-ct-3';

TBEV-S(R) 5' -gc(c/t)-gt(c/t)-gga-agg-tgt-tcc-aga-3' [12].

Состав реакционной смеси для ПЦР: 0,5 мкл пробы (50 нг), однократный буфер для ПЦР без магния («Sybenzyme»), 3 мM MgCl 2,200 мкмоль смеси дезоксинуклеозидтрифосфатов («Sybenzyme»), прямой и обратный праймеры по 10 пмоль каждого («Syntol»), 1,25 ед. а. Таq-полимеразы («Sybenzyme»), вода до конечного объема 10 мкл.

Условия ПЦР: 1 цикл денатурации $-94^{\circ} \mathrm{C}, 5$ мин.; 40 циклов $-94^{\circ} \mathrm{C}, 30$ сек.; $57^{\circ} \mathrm{C}, 30$ сек. и $72^{\circ} \mathrm{C}$, 30 сек.; 1 цикл достройки $-72^{\circ} \mathrm{C}, 5$ мин.

Продукты амплификации разделяли в 6\% нативном полиакриламидном геле, который окрашивали бромистым этидием [11].

\section{Результаты и обсуждение}

В период с 2007 по 2016 гг. было исследовано 1376 клещей из 27 районов Кировской области. Для анализа выбраны только районы, в которых клещей собирали более трех лет. К таким районам относятся Зуевский, Кирово-Чепецкий, Оричевский, Слободской, Тужинский районы и город Киров. Районы расположены таким образом, что г. Киров граничит с Оричевским, Кирово-Чепецким и Слободским районами, Кирово-Чепецкий район имеет общие границы с г. Кировом, Оричевским, Слободским и Зуевским районами, Зуевский район граничит с Кирово-Чепецким и Слободским районами. Тужинский район расположен на юго-западе области обособленно от остальных районов.

На территории города Кирова и в Кирово-Чепецком районе сбор клещей проводился с 2007 по 2016 г. В Оричевском районе сбор проводился с 2007 по 2011 гг. и с 2013 по 2016 гг. При этом в окрестностях города Кирова было собрано 342 клеща, в Кирово-Чепецком районе - 80, в Оричевском - 128 клещей. В период с 2009 по 2015 гг. сбор проводился 
на территории Тужинского района, с 2011 по 2016 гг. - в Слободском районе. В Зуевском районе клещей собирали с 2009 по 2016 гг., за исключением 2010 и 2014 гг. Количество собранных в этих районах клещей 97,82 и 58 соответственно. Все образцы клещей были проанализированы на зараженность европейской и сибирской изоформами вируса клещевого энцефалита.
На территории Кирова наблюдаются 3 пика зараженности европейской изоформой вируса (рис. 1). В 2009 году процент зараженности составил 4,8\%, в 2011 году $-14,3 \%$ и в 2016 году - 4,6\%. При этом наблюдается постепенное расширение пиков и увеличение времени между ними. Низкий процент зараженности возможно связан с обработкой территории акарицидами.

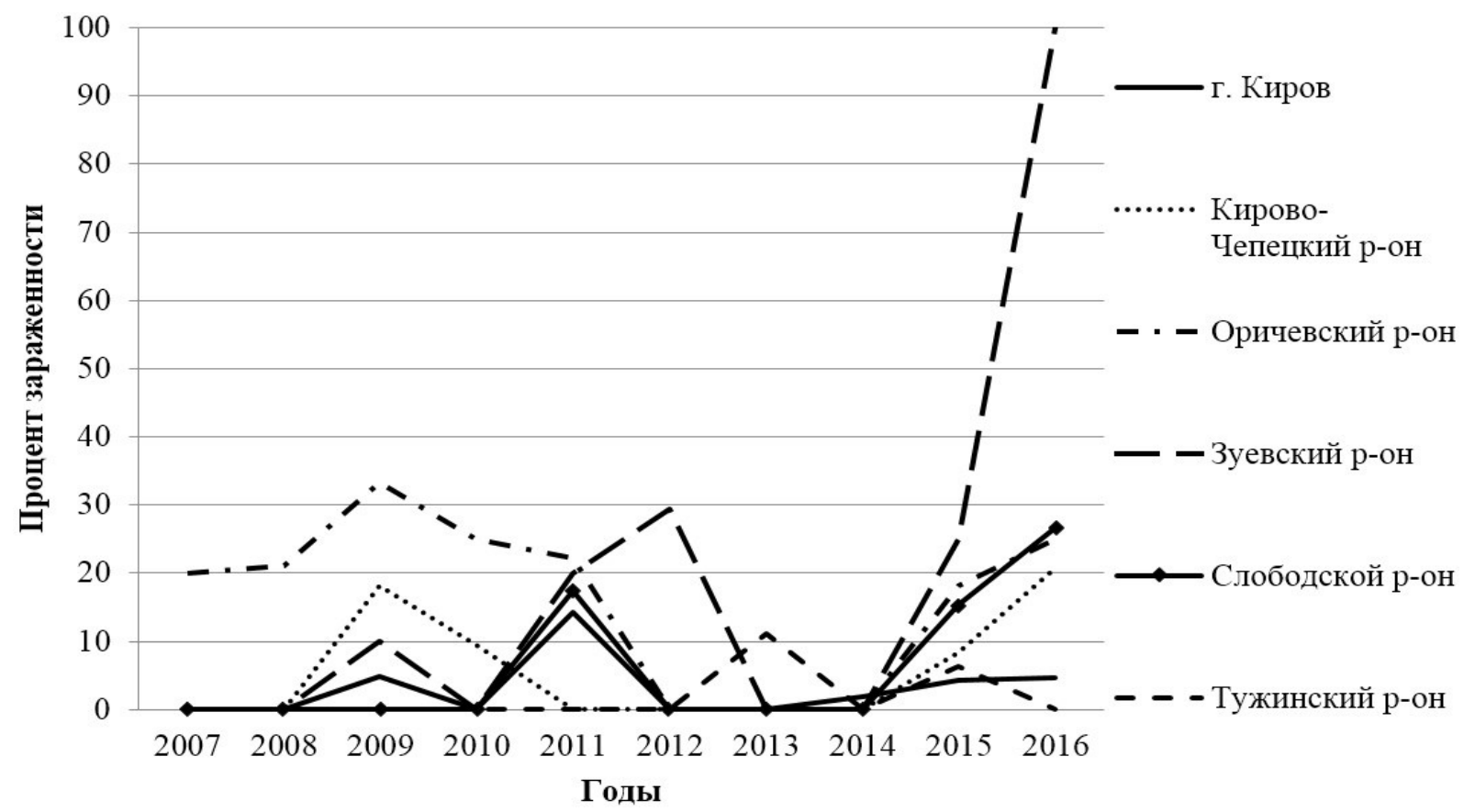

Рисунок 1 - Динамика процента зараженности клещей европейской изоформой вируса клещевого энцефалита в г. Кирове, Кирово-Чепецком, Оричевском, Зуевском, Слободском и Тужинском районах

В Оричевском районе наблюдаются 2 пика зараженности: в 2009 году $(33,3 \%)$ и в 2016 году $(25 \%)$. Для первого пика характерно расширение: зараженность клещевым энцефалитом фиксировалась с 2007 по 2011 гг. с максимальным значением в 2009 г.

В Кирово-Чепецком районе наблюдаются 2 пика с большим периодом в 2009 году $(18,2 \%)$ и в 2016 году $(20,8 \%)$. Совпадение пиков зараженности в Оричевском и Кирово-Чепецком районах связано с наличием общей протяженной границы.

В Зуевском районе наблюдаются 3 пика: в 2009 $(10 \%)$, в $2012(29,4 \%)$ и в 2016 гг. (100\%).

В Слободском районе выделятся 2 пика: в 2011 $(17,4 \%)$ и в 2016 году $(26,7 \%)$. Эти пики соотносятся с пиками 2011 и 2016 гг. в г. Кирове и в 2012 и 2016 гг. в Зуевском районе. С этими районами Слободской район имеет общие границы.

В Тужинском районе до 2013 года не было выявлено случаев заражения клещей европейской изоформой клещевого энцефалита. Это связано с тем, что в этом районе в основном были собраны клещи вида Dermacentor reticulatus, которые имеют более низкий процент зараженности, чем Ixodes persulcatus [15]. Однако наблюдается постепенное увеличение процента зараженности. Пики зараженности достаточно узкие и частые $(2013$ год - 11,1\%, 2015 год $6,25 \%)$.

Таким образом, динамика зараженности европейской изоформой вируса клещевого энцефалита имеет вид пиков. Период появления пиков колеблется от 3 до 6 лет.
Сибирская изоформа вируса клещевого энцефалита являлась нехарактерной для Кировской области, поэтому до 2011 года она не обнаруживалась.

В Оричевском, Зуевском и Слободском районах пики зараженности появляются раньше, чем в других районах (рис. 2). Появление сибирской изоформы может объясняться тем, что эти районы расположены восточнее всех изучаемых районов.

Позднее сибирская изоформа появляется в г. Кирове, Кирово-Чепецком и самом западном Тужинском районе, что свидетельствует о постепенном проникновении изоформы на всей территории области.

Таким образом, первый пик приходится на 20112012 гг. В этот период зараженность клещей сибирской изоформой составила $16,7 \%$ в Оричевском районе (2011 г.), 17,6\% в Зуевском (2012 г.) и 30,4\% и $100 \%$ в Слободском райне в 2011 и 2012 гг. соответственно. Второй пик приходится на 2015 г. процент зараженности в этом году составил $8,3 \%$ в Кирово-Чепецком районе, $18,2 \%$ - в Оричевском, $50 \%$ в Зуевском и $38,5 \%$ - в Слободском. В Тужинском районе сибирская изоформа вируса появляется в 2014 и 2015 гг., процент зараженности составил 8,3\% и $12,5 \%$. Также с 2015 г. эта изоформа появляется на территории города Кирова. Максимальное значение процента зараженности составило 6,9\% (2016 г.).

Период возрастания частоты зараженности составляет примерно 3 года.

Установленные пики зараженности клещей вирусом энцефалита совпадают с данными центра Роспотребнадзора о динамике показателей заболеваемости населения клещевым энцефалитом в изучаемых районах области [16]. 


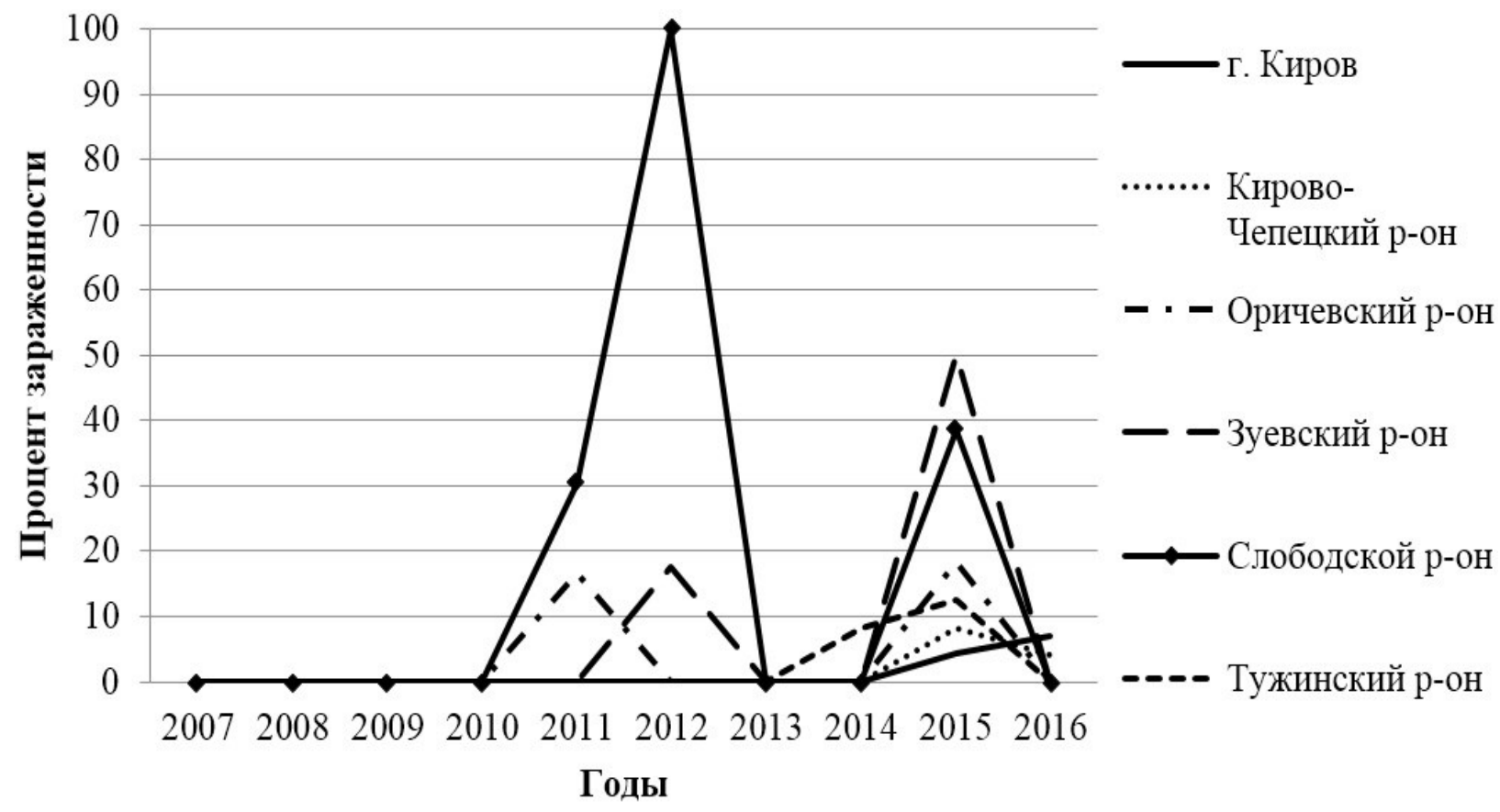

Рисунок 2 - Динамика процента зараженности клещей сибирской изоформой вируса клещевого энцефалита в г. Кирове, Кирово-Чепецком, Оричевском, Зуевском, Слободском и Тужинском районах

\section{Bblводbl}

В результате проведенных исследований установлена динамика процента клещей, зараженных вирусом клещевого энцефалита. Динамика зараженности европейской изоформой вируса характеризуется периодичностью, которая частично совпадает в районах, имеющих общие границы. Эта динамика имеет вид пиков, период которых колеблется от 3 до 6 лет. С 2011 года в Кировской области наблюдаются случаи заражения клещей сибирской изоформой вируса. Период возрастания частоты зараженности составляет примерно 3 года. На распространение этой изоформы на территории региона указывает обнаружение ее в западных районах области в последнее время.

\section{СПИСОК ЛИТЕРАТУРЫ:}

1. Lindquist L., Vapalahti O. Tick-borne encephalitis // Lancet. 2008. V. 371, №5. P. 1861-1871.

2. Казанцев А.П., Матковский В.С. Справочник по инфекционным болезням. М.: Медицина, 1985. 184 с.

3. Токаревич К.Н. Важнейшие инфекционные болезни, общие для животных и человека. Л.: Медицина, 1979. $221 \mathrm{c.}$

4. Randolph S.E. Tick ecology: processes and patterns behind the epidemiological risk posed by ixodid ticks as vectors // Parasitology. 2004. V. 129 Suppl. P. 37-65.

5. Столбова Ф.С., Бердинских И.С. Осенняя активность клещей рода Dermacentor Koch. на югозападе Кировской области // Проблемы биомониторинга и биоиндикации: сб. мат-лов VIII всерос. науч.-практ. конф. Киров; 2010. Ч. 2. С. 17-21.

6. Biernat B., Karbowiak G., Werszko J., Stanzak J. Prevalence of tick-borne encephalitis virus (TBEV) RNA in Dermacentor reticulatus ticks from natural and urban environment, Poland // Exp Appl Acarol. 2014. V. 64. P. 543-551.

7. Tonteri E., Jääskeläinen A.E., Tikkakoski T., Voutilainen L., Niemimaa J., Henttonen H., Vaheri A., Vapa- lahti O. Tick-borne encephalitis virus in wild rodents in winter, Finland, 2008-2009 // Emerg Infect Dis. 2011. V. 17. P. $72-75$.

8. Юрченко О.А., Виноград Н.А., Дубина Д.А. Молекулярно-генетическая характеристика вируса клещевого энцефалита в Крыму // Вопросы вирусологии. 2012. Т. 57, № 3. С. 40-44.

9. Иерусалимский А.П. Клещевой энцефалит. Руководство для врачей. Новосибирск, 2001. 359 с.

10. Филиппова Н.А. Таежный клещ Ixodes persulcatus Schulze (Acrania, Ixodidae): морфология, систематика, экология, медицинское значение. Л.: Наука, 1985, T. 1,352 c.

11. Sambrook J., Fritch T., Maniatis T. Molecular cloning: a laboratory manual. NY: Cold Spring Harbor Laboratory Press, 1989.

12. Ruzek D., St`astna H., Kopecky J., Golovljova I., Grubhoffer L. Rapid subtyping of tick-borne encephalitis virus isolates using multiplex RT-PCR // J. Virol. Met. 2007. Vol. 144. P. 133-137.

13. Пышкин В.Б., Евстафьев И.Л., Евстафьев А.И. К экологии и биоразнообразию рода Dermacentor Koch., иксодиофауны Крыма (Acrania, Ixodidae) // Экосистемы Крыма, их оптимизация и охрана. 2006. C. 30-35.

14. Sahai H., Anwer Khurshid H. On analysis of epidemiological data involving A 2 X2 contingency table: an overview of fisher's exact test and yates' correction for continuity // Journal Biopharm. Stat. 1995. V. 1, №1. P. 43-70.

15. Бессолицына Е.А., Волков С.А., Столбова Ф.С., Дармов И.В. Анализ зараженности клещей вирусом клещевого энцефалита на территории Кировской области // Инфекция и иммунитет. 2014. Т. 4, № 3. C. 275-278.

16. Управление федеральной службы по надзору в сфере защиты прав потребителей и благополучия человека по Кировской области [Электронный реcурc] // http://43.rospotrebnadzor.ru. 


\section{DYNAMICS OF TICKS' INFECTION WITH A TICK-BORNE ENCEPHALITIS VIRUS IN SOME AREAS OF KIROV REGION}

(C) 2017

Bessolitsyna Ekaterina Andreevna, candidate of biological sciences, associate professor of Microbiology Department

Nozdrina Elena Vasil'evna, student of Institute of Biology and Biotechnology

Volkov Stanislav Alexandrovich, postgraduate student of Microbiology Department Vyatka State University (Kirov, Russian Federation)

Abstract. In this research we studied the dynamics of infestation of ticks with European and Siberian isoforms of tick of tick-borne encephalitis virus collected from 2007 to 2016 from vegetation cover, domestic animals and clothes in Kirov, Kirovo-Chepetsk, Orychevsky, Zuevsky, Slobodsky and Turinsky districts of Kirov Oblast. All collected samples were analyzed for the presence of tick-borne encephalitis virus in them. The virus isoforms were detected by reverse transcription - polymerase chain reaction (RT-PCR). The analysis revealed the dynamics of the percentage of ticks infected with isoforms of tick-borne encephalitis virus. In the central regions, which share common borders, it was revealed the coincidence of the peaks of infection with the European isoform virus, but further studies are needed to determine the periodicity. It was also noted that for some areas, the maximum peak of infection and the increase in the time between peaks are characteristic. A low percentage of contamination in the territory of Kirov city could be associated with treatment with acaricides. Since 2011, in the Kirov region, there have been cases of ticks infected with tick-borne encephalitis virus from the Siberian isoform. Every year there is an intensive penetration of the Siberian isoform westward through the territory of the Kirov Region. Periodicity of peaks is approximately 3 years.

Keywords: tick-borne encephalitis; virus encephalitis; isoforms of tick-borne encephalitis virus; Dermacentor reticulatus; Ixodes persulcatus; ticks; RNA; identification; reverse transcription; polymerase chain reaction; Kirov Region; Kirov.

УДК 574.472

\section{РАСТИТЕЛЬНЫЙ ПОКРОВ И СООБЩЕСТВА МЕЛКИХ МЛЕКОПИТАЮЩИХ КАК КОМПОНЕНТЫ БИОЦЕНОЗА В УСЛОВИЯХ НИЖЕГОРОДСКОГО ПРЕДВОЛЖЬЯ} (C) 2017

Борякова Елена Евгеньевна, кандидат биологических наук, доцент кафедры ботаники и зоологии Национальный исследовательский Нижегородский государственный университет имени Н.И. Лобачевского (2. Нижний Новгород, Российская Федерация)

Аннотация. Статья посвящена исследованию биоценозов памятника природы «Дубрава у с. ПеляХованская». Это уникальный лесной массив со сложной структурой, находящийся в лесостепной зоне Нижегородской области, характеризующийся высоким видовым разнообразием мелких млекопитающих и растительного покрова, что указывает на сложность трофических и пространственных связей. Заложена 41 пробная площадь $20 \times 20$ м и серии раункиеровских площадок $1 \times 1$ м, всего 300 ; определялось обилие видов по шкале Браун-Бланке и численность экземпляров подроста. Для учета млекопитающих применяли отлов ловушками, метод ловчих канавок и трансекты. В растительном покрове характерно наличие четкой внутриценотической дифференциации и существования двух основных эколого-ценотических групп - неморальнолесной (центральный вид медуница неясная Pulmonaria obscura Dum.) и лугово-опушечной. Наиболее выраженную группу образуют лесоопушечные виды, что объясняется, в целом, скорее лесостепным, чем неморальным характером растительности. Мелкие млекопитающие представлены следующими видами: обыкновенная и малая бурозубки, малая лесная, желтогорлая и полевая мыши и мышь-малютка, полевка-экономка, обыкновенная, пашенная и рыжая полевки, европейский крот. Из них 2 вида - полевка-экономка и мышьмалютка - внесены в Красную Книгу Нижегородской области. При сопоставлении ходов мышевидных грызунов с богатством почвы азотом и влажностью наблюдается два хорошо выраженных пика. Наибольшее количество ходов обнаруживается в местах, где почва богата азотом. Крот тяготеет к участкам с большим проективным покрытием первоцвета весеннего - коэффициент Спирмена 0,50; кроме того, наблюдается отрицательная корреляция числа кротовин с проективным покрытием пиретрума щиткового $(-0,46)$, являющегося маркером наиболее сухих участков массива. В целом, ООПТ «Дубрава у с. Пеля-Хованская» представляет значительный интерес как с ботанической, так и с зоологической точек зрения. Многолетние исследования биоценозов позволят проводить мониторинг объекта и корректировать предполагаемые охранные мероприятия.

Ключевые слова: дубрава у с. Пеля-Хованская; особо охраняемые природные территории; мелкие млекопитающие; Нижегородская область; Нижегородское Предволжье; видовое богатство; растительный покров; экоценотическая группа; корреляционные плеяды; пространственная структура сообществ микроммалий.

Актуальность исследований

Изучение природных экосистем в настоящее время является одной из приоритетных задач в области экологических исследований. Согласно Указу президента РФ от 1 августа 2015 года, № 392, 2017 год в связи с исполняющимся 100-летием создания в Рос- 